\title{
ESTIMATION OF GENETIC AND PHENOTYPIC PARAMETERS OF BODY MEASUREMENTS AND CONFORMATION IN ARABIAN HORSES
}

\author{
M. H. Sadek
}

Department of Animal Production, Faculty of Agriculture, Ain Shams University, P.O. Box 68, Hadayeq Shoubra, 11241 Cairo, Egypt

\section{SUMMARY}

Data of eleven body measurements and eight body conformation indices on 280 purebred Arabian horses ranging from 1 month to 298 months old. These horses were progeny of 60 stallions and 176 mars.

A multiple trait animal model was used to estimate heritability genetic and phenotypic correlations for the measurements and indices under investigation.

Heritability estimates were 0.35, 0.51, 0.53, 0.33, 0.27, 0.29, 0.28 0.22, 0.14, 0.18 and 0.55 for neck girth, chest girth, fore cannon bone circumference, hind cannon bone circumference, back line length, body length, chest width, croup width, chest depth, wither height and croup height, respectively. For body conformation indices, heritability estimates were 0.11, 0.09, 0.15, 0.23, 0.27, 0.29, 0.16 and 0.25 for format, compactness, rib cage, chest depth, chest girth, boniness, body length and height, respectively.

Genetic correlation coefficients between body measurements were all positive, and ranged from 0.12 to 0.96, except that between the chest depth and body length (0.03). Genetic correlation coefficients between body conformation indices were low to moderate and some were negative. Phenotypic correlation coefficients for body measurements were all positive and ranged from 0.08 to 0.86. For conformation indices, some of the estimates were positive and some others were negative.

Therefore, body measurements and/or body conformation indices can be efficiently used to accomplish certain breeding program goals that are related to body measurements and conformation of the Arabian horse.

Keywords: Arabian horse, Body measurements, Conformation index, Genetic parameters

\section{INTRODUCTION}

Conformation traits play an important role in horse breeding because they are associated with desirable characterization and performance traits of the animals. Several Arabian horse shows for studbook judging and evaluation are arranged yearly in Egypt. Poor soundness related to defects in conformation is an obvious reason for low grade and poor performance of the horses. Good conformation and movements are important factors for horses to fetch high prices ( Saastamoinen et al., 1991). The body conformation is useful in evaluating and comparing breeds (Lawrence, 2001 and Meadows, 2003). Beauty of horses and their athletic performance are affected by their body conformation. (Evans, 2000; Lawrence, 2001; Parker, 2002 and Meadows, 2003). Iriarte-Diaz (2002) stated that body indices were good scale for body

Issued by The Egyptian Society of Animal Production 
conformation and as selection criteria. Part of the beauty of the Arabian horse depends on its body conformation, body measurements and the relationships between these measurements.

To the author's knowledge, there are no studies on estimating genetic parameters for body measurements and conformation traits of the Arabian horse breed in Egypt. Knowledge of genetic components associated with conformation would allow the design of breeding programs for the breed.

The aim of the present work was to estimate genetic and phenotypic parameters for eleven body measurements and eight body indices for conformation of the pure Arabian horse in Egypt.

\section{MATERIAL AND METHODS}

Data were collected on 11 body measurements on 280 pure-bred registered Arabian horses from the Alzahraa stud, the largest stud of registered Arabian horses in Egypt. The stud is a member of the World Arabian Horse Organization (WAHO, 2004). The horses were 95 males ( 43 stallions and 53 colts) and 185 females (123 mares and 61 fillies). These hoses were the progeny of 60 sires and 176 dams and the age of the horses the time of measurement ranged from 1 to 298 months. Therefore, when age was considered in the statistical analysis, horses were classified into 20 age groups of 6 months interval. One group included horses over 10 years old to avoid disconnectedness in the data.

Horses are raised in a closed herd. They are fed roughage and concentrate supplemented with minerals and vitamins. Roughage is fed ad lib in group feeding and consists of alfalfa hay or Egyptian clover, Trifolium alexandrinum, hay. Barley is fed as a concentrate source with mineral and vitamin supplements. The concentrate mixture is offered individually three times a day. Water is available all day. The horses were given regular daily exercise.

As shown on figures 1, 2 and 3, eleven body measurements (in $\mathrm{cm}$ ) were taken:

1 - The neck girth, i.e. girth of the neck at the area of attachment between the neck and breast;

2- chest girth, i.e. circumference around the chest behind the front legs;

3 - fore cannon circumference, i.e. girth of the fore cannon bone at the middle point of its length;

4- hind cannon circumference, i.e. girth of the hind cannon bone at the middle point of its length;

5 - back line length, i.e. length from the pin bone to the highest point of the withers;

6- body length, i.e. the distance from the shoulder to the point of the tuber ischium with a sloping line;

7- wither height, i.e. distance from highest point of wither to the ground;

8- croup height, i.e. distance from the highest point of croup, tuber sacral, to ground;

9- chest depth, i.e. distance from the highest dorsal point of chest to the sternum (parallel point at the chest floor);

10- chest width, i.e. distance from the middle point of the front part of chest to the same point on the opposite side;

11- croup width, i.e. the distance from the tuber sacral of hip from one side to same point on the opposite side. 


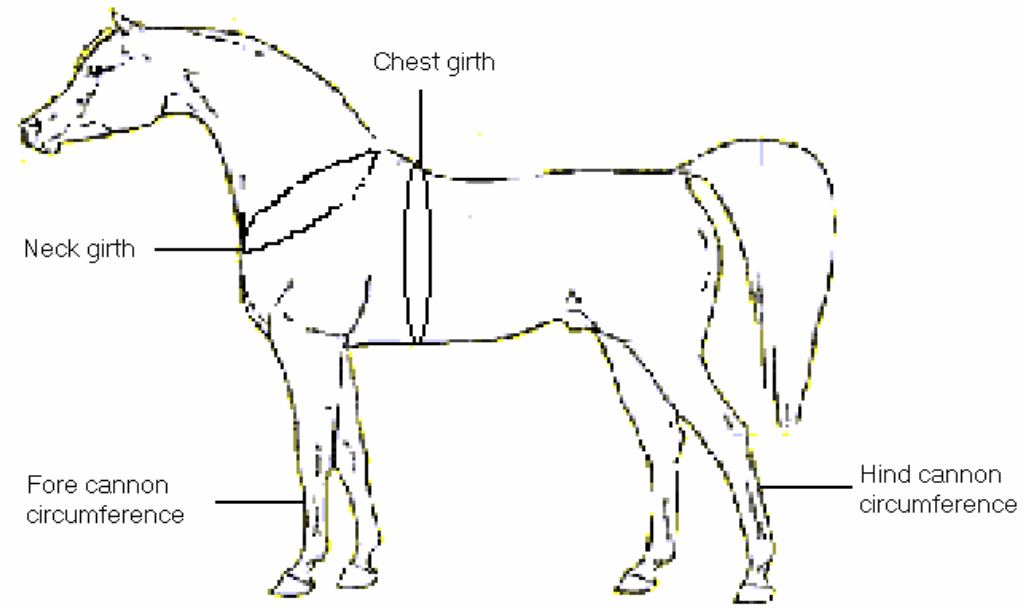

Figure 1. Girth measurements

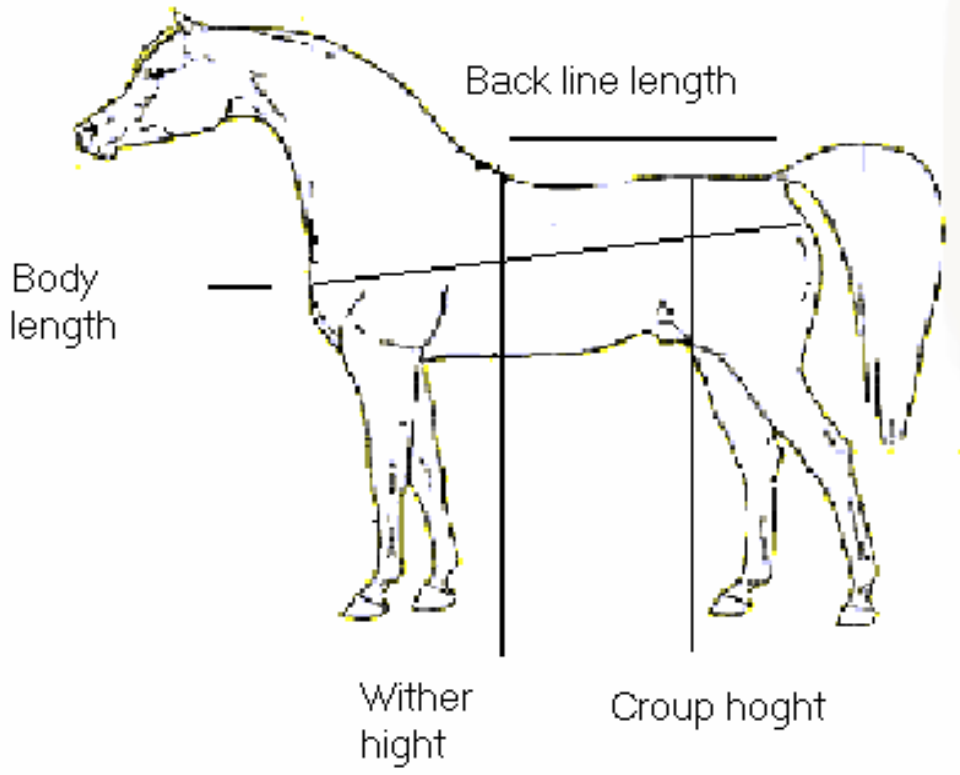

Figure 2. Linear measurements of lengths and heights 


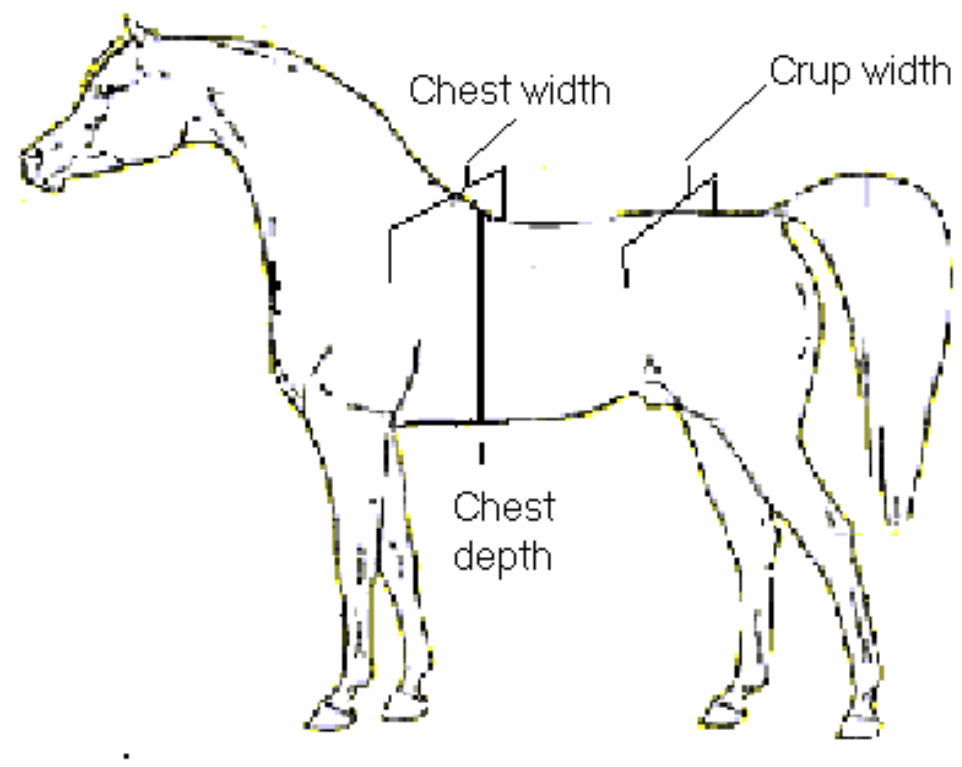

Figure 3. Linear measurements of widths and chest depth

All measurements were taken on the left side of the horse while it was standing on flat ground with all feet on the ground and legs parallel. Circumference measurements were taken using a tape measure while the other measures were taken with a specially designed caliper.

Horses were evaluated for eight body conformation indices according to Pietrazak an Wojciechowski (1992) and Alagic et al., (2002). These indices were:

(1) Format index $=$ (body length /wither height) X 100.

This index can provide a good idea about the coordination among body parts and gives an idea about the general form.

(2) Compactness $=($ chest girth $/$ body length $)$ X 100.

This index gives information on the degree of compactness of the trunk and the coordination between body girth and length.

(3) Rib cage index $=$ (chest width/chest depth) $X 100$.

It is a scale indicating the chest volume and it could reflect the respiratory capacity of the chest.

(4) Chest depth index $=$ (chest depth / wither height) $\mathrm{X} 100$.

It can measure the height of chest, height of legs and the degree of chest depth in comparison to the height of horse. The length of the legs, in general should preferably not be the same as the chest depth (Evans, 2000, Parker, 2002 and Meadows, 2003).

(5) Chest girth index $=($ chest girth $/$ wither height $) \times 100$. 
This index expresses the volume of the chest in comparison with the general height of the horse.

(6) Boniness index $=$ (fore cannon circumference / wither height) 100.

This relates the thickness of the horse's bones compared with its height and can reflect the capacity of the horse in all gaits, jumping and in carrying a rider while remaining well balanced.

(7) Body length index $=$ (body length $/$ back line length) $X 100$.

Loch et al. (2000), Parker (2002) and Meadows (2003) reported that the back line length should be shorter than underline length. It increases the height and length of stride and leads to a good athletic ability.

(8) Height index = (wither height /croup height) $X 100$.

The ratio between wither height and croup heights could give an idea about the balance between these two heights. Evans (2000) and Meadows (2003) reported that a properly balanced horse will be higher at the wither than at the croup. When wither height is higher than croup height, the hindquarters are positioned more under the body, which enhances the athletic ability of the horse.

Data for the eleven body measurements and eight indices were analyzed separately using the following animal model by utilizing the multiple-trait derivative free restricted maximum likelihood (DFREML) programs (Meyer, 1998):

where:

$$
\mathrm{y}=\mathrm{Xb}+\mathrm{Za}+\mathrm{e}
$$

$y$ is a vector of observations of the eleven body measurements or the eight indices;

$\mathrm{b}$ is a vector of fixed effects (sex, 2 levels, and age in months, 21 levels);

a is a vector of random additive direct genetic effects;

$\mathrm{e}$ is a vector of random residual effects; and

$\mathrm{X}$ and $\mathrm{Z}$ are known incidence matrices relating observations to the respective fixed and random effects with $\mathrm{Z}$ augmented with columns of zeros for animals without records.

The first and the second moments of the model were assumed to be:

$\mathrm{E}(\mathrm{y})=\mathrm{Xb}, \mathrm{E}(\mathrm{a})=\mathrm{E}(\mathrm{e})=0$;

$V\left[\begin{array}{l}a_{i} \\ e_{i}\end{array}\right]=\left[\begin{array}{cc}A \otimes J a_{i} & 0 \\ 0 & I_{n} \otimes \sigma_{e_{i}}^{2}\end{array}\right]$

$A$ is the additive numerator relationship matrix for horses. The full pedigree of all horses were available. $J$ is a matrix of 1 's of order $11 \times 11$ or $8 \times 8 . I_{n}$ is an identity matrix of order equal the number of horses $(n)$. Symbol $\otimes$ means the direct product of two matrices. Subscript i refers to the eleven measurements or the eight indices.

\section{RESULTS AND DISCUSSIONS}

Means, minimum, maximum, standard error and coefficient of variation for each of the eleven body measurements and the eight conformation indices are presented in tables 1 and 2, respectively. The results showed that there were high variation in the data for chest width, croup width, neck girth, chest depth, chest girth and back line length. However, there was low variation in the other measurements. The rib cage index showed higher variation than other indices. 
Table 1. Descriptive statistics of the eleven studied measurements $(\mathrm{cm}, \mathbf{N}=\mathbf{2 8 0})$

\begin{tabular}{lccrcl}
\hline Measure & Minimum & Maximum & Mean & SE & CV\% \\
\hline Age (months) & 1 & 298 & 83.5 & 4.33 & 86.8 \\
Neck girth & 62 & 130 & 104.6 & 0.71 & 11.4 \\
Chest girth & 102 & 193 & 166.6 & 1.00 & 10.7 \\
Cannon bone circumference & & & & & \\
(fore leg) & 14 & 22 & 19.3 & 0.07 & 6.9 \\
Cannon bone circumference (hind leg) & 14 & 22 & 18.3 & 0.07 & 6.4 \\
Back line length & 62 & 115 & 99.7 & 0.57 & 9.6 \\
Body length & 90 & 158 & 139.9 & 0.74 & 8.9 \\
Chest width & 23 & 58 & 42.1 & 0.36 & 14.6 \\
Croup width & 26 & 57 & 47.8 & 0.34 & 12.2 \\
Chest depth & 39 & 74 & 64.9 & 0.43 & 11.1 \\
Wither height & 110 & 157 & 144.6 & 0.53 & 6.2 \\
Croup height & 111 & 157 & 145.0 & 0.50 & 5.8 \\
\hline
\end{tabular}

Table 2. Descriptive statistics of the eight studied indices (in percent, $N=\mathbf{2 8 0}$ )

\begin{tabular}{lcclcl}
\hline Index & Minimum & Maximum & Mean & SE & CV\% \\
\hline Format index & 80.0 & 105.0 & 96.6 & 0.27 & 4.7 \\
Compactness index & 80.7 & 135.6 & 119.0 & 0.32 & 4.6 \\
Rib cage index & 50.0 & 90.2 & 64.9 & 0.36 & 9.5 \\
Chest depth index & 35.1 & 50.4 & 44.8 & 0.17 & 6.4 \\
Chest girth index & 81.3 & 132.9 & 114.9 & 0.42 & 6.2 \\
Boniness index & 10.7 & 14.1 & 12.4 & 0.03 & 4.5 \\
Body length index & 120.0 & 161.3 & 140.8 & 0.34 & 4.1 \\
Height index & 95.3 & 104.9 & 99.8 & 0.08 & 1.4 \\
\hline
\end{tabular}

\section{Heritability}

It is well known that the estimates of heritability vary according to the size of data, model and method of analysis. In addition, the available reports in the literature deal with different horse breeds. Therefore, it was impractical to compare the results of the present work with that reported in the literature. However, this comparison could be legitimate from the standpoint of showing trends of the estimates.

Tables 3 shows heritability estimates for the eleven studied body measurements. These estimates ranged from low, less than 0.2 or medium, more than 0.2 to less than 0.3 , to high, over 0.3 . For body measurements, the lowest heritability was for the chest depth, 0.14, while the highest estimate was for croup height, 0.55. Costa et al.(1997) reported heritability of 0.52 in the Brasileira pony breed. In the thoroughbred horse, Fedorski and Pikuta (1987) reported heritability of 0.28, 0.44 and 0.12 for wither height, chest girth and fore cannon circumference, respectively. In the present study, these estimates were $0.18,0.51$ and 0.53 for the same measurements, respectively. Miserani et al. (2002) investigating the pantaneiro horse, and Sasstamoinen et al. (1991), investigating the Finn horse, reported higher heritability estimates for all measurements than those recorded in the present work. Molina et al. (1999) reported moderate to high (0.35 to 0.95$)$ heritability estimates 
for body measurements in the Andalusian horse. In the Haflinger horse, Samore et al. (1997) reported heritability estimates from 0.02 to 0.53 for body measurements. These were somewhat higher than those reported by Koenen et al. (1995) in the Dutch warm-blood riding horse. It can be noticed that the tendency in most cases is towards medium to high heritability while individual values within breeds vary greatly due to different selection criteria and management systems.

Table 3. Heritability estimates (diagonal and underlined), genetic correlations (below diagonal), phenotypic correlations (above diagonal) among the eleven body measurements

\begin{tabular}{|c|c|c|c|c|c|c|c|c|c|c|c|}
\hline Measure & $\begin{array}{l}\text { Neck } \\
\text { girth }\end{array}$ & $\begin{array}{l}\text { Chest } \\
\text { girth }\end{array}$ & $\begin{array}{l}\text { Fore } \\
\text { cannon } \\
\text { cerc. }\end{array}$ & $\begin{array}{l}\text { Hind } \\
\text { cannon } \\
\text { cerc. }\end{array}$ & $\begin{array}{l}\text { Back } \\
\text { line } \\
\text { length }\end{array}$ & $\begin{array}{l}\text { Body } \\
\text { length }\end{array}$ & $\begin{array}{l}\text { Chest } \\
\text { width }\end{array}$ & $\begin{array}{l}\text { Croup } \\
\text { width }\end{array}$ & $\begin{array}{l}\text { Chest } \\
\text { depth }\end{array}$ & $\begin{array}{l}\text { Wither } \\
\text { height }\end{array}$ & $\begin{array}{l}\text { Croup } \\
\text { height }\end{array}$ \\
\hline $\begin{array}{l}\text { Neck } \\
\text { girth }\end{array}$ & $\underline{0.35}$ & 0.69 & 0.48 & 0.53 & 0.30 & 0.26 & 0.33 & 0.49 & 0.62 & 0.54 & 0.39 \\
\hline $\begin{array}{l}\text { Chest } \\
\text { girth }\end{array}$ & 0.89 & $\underline{0.51}$ & 0.49 & 0.51 & 0.34 & 0.25 & 0.35 & 0.52 & 0.64 & 0.59 & 0.59 \\
\hline $\begin{array}{l}\text { Fore } \\
\text { cannon } \\
\text { cerc. }\end{array}$ & 0.82 & 0.73 & $\underline{0.53}$ & 0.86 & 0.37 & 0.29 & 0.48 & 0.54 & 0.24 & 0.49 & 0.61 \\
\hline $\begin{array}{l}\text { Hind } \\
\text { cannon } \\
\text { cerc. }\end{array}$ & 0.89 & 0.85 & 0.93 & $\underline{0.33}$ & 0.31 & 0.28 & 0.47 & 0.53 & 0.29 & 0.51 & 0.53 \\
\hline $\begin{array}{l}\text { Back } \\
\text { line } \\
\text { length }\end{array}$ & 0.31 & 0.16 & 0.57 & 0.28 & $\underline{0.27}$ & 0.64 & 0.37 & 0.39 & 0.26 & 0.41 & 0.35 \\
\hline $\begin{array}{l}\text { Body } \\
\text { length }\end{array}$ & 0.22 & 0.06 & 0.65 & 0.32 & 0.77 & $\underline{0.29}$ & 0.33 & 0.33 & 0.18 & 0.29 & 0.25 \\
\hline $\begin{array}{l}\text { Chest } \\
\text { width }\end{array}$ & 0.66 & 0.72 & 0.67 & 0.64 & 0.12 & 0.44 & $\underline{0.28}$ & 0.53 & 0.08 & 0.36 & 0.42 \\
\hline $\begin{array}{l}\text { Croup } \\
\text { width }\end{array}$ & 0.87 & 0.95 & 0.88 & 0.94 & 0.32 & 0.26 & 0.67 & $\underline{0.22}$ & 0.35 & 0.61 & 0.54 \\
\hline $\begin{array}{l}\text { Chest } \\
\text { depth }\end{array}$ & 0.96 & 0.87 & 0.67 & 0.82 & 0.19 & -0.03 & 0.47 & 0.81 & $\underline{0.14}$ & 0.58 & 0.28 \\
\hline $\begin{array}{l}\text { Wither } \\
\text { height }\end{array}$ & 0.89 & 0.77 & 0.77 & 0.81 & 0.53 & 0.20 & 0.31 & 0.82 & 0.91 & $\underline{0.18}$ & 0.51 \\
\hline $\begin{array}{l}\text { Croup } \\
\text { height }\end{array}$ & 0.69 & 0.83 & 0.84 & 0.77 & 0.45 & 0.50 & 0.81 & 0.89 & 0.54 & 0.59 & $\underline{0.55}$ \\
\hline
\end{tabular}

Table 4. shows heritability estimates for the eight body conformation indices. These estimates ranged from 0.09 to 0.29 for compactness and boniness, respectively. Most of the heritability estimates of body conformation indices that were suggested to be related to the athletic ability of a horse such as boniness, chest girth and height indices were medium $(0.29,0.27$ and 0.25 , respectively). 
Table 4. Heritability estimates (diagonal and uderlined), genetic correlations (below diagonal), phenotypic correlations (above diagonal) among the eight conformation indices

\begin{tabular}{lcccccccc}
\hline Index & Format & Compactness & $\begin{array}{c}\text { Rib } \\
\text { cage }\end{array}$ & $\begin{array}{c}\text { Chest } \\
\text { depth }\end{array}$ & $\begin{array}{c}\text { Chest } \\
\text { girth }\end{array}$ & Boniness & $\begin{array}{c}\text { Body } \\
\text { length }\end{array}$ & Height \\
\hline Format & $\underline{0.11}$ & -0.15 & 0.14 & 0.35 & 0.37 & 0.18 & 0.51 & -0.18 \\
Compactness & 0.63 & $\underline{0.09}$ & 0.29 & 0.15 & 0.66 & 0.07 & -0.25 & -0.07 \\
Rib cage & 0.34 & 0.43 & $\underline{0.15}$ & -0.21 & 0.42 & 0.17 & 0.23 & -0.12 \\
Chest depth & 0.61 & 0.52 & -0.35 & $\underline{0.23}$ & 0.44 & 0.09 & 0.14 & -0.03 \\
Chest girth & 0.89 & 0.92 & 0.43 & 0.62 & $\underline{0.27}$ & 0.22 & 0.18 & -0.21 \\
Boniness & -0.21 & -0.54 & -0.22 & -0.16 & -0.43 & $\underline{0.29}$ & -0.07 & -0.10 \\
Body length & 0.41 & 0.07 & 0.40 & 0.17 & 0.24 & -0.32 & $\underline{0.16}$ & 0.02 \\
Height & -0.28 & -0.11 & -0.23 & 0.29 & -0.23 & 0.37 & 0.17 & $\underline{0.25}$ \\
\hline
\end{tabular}

\section{Genetic and phenotypic correlations}

Table 3 presents estimates of genetic and phenotypic correlations between different body measurements. For body measurements, genetic correlations were all positive except the genetic correlation between chest depth and body length with a value of -0.03 . Other genetic correlations ranged from 0.12 to 0.96 between chest width and back line length and between chest depth and neck girth, respectively. Most of the genetic correlations between body measurements were found to be high. In the Brazilian Pony breed, genetic correlation varied between 0.32 to 1.0 (Costa et al., 1997), the lowest between back line length and chest width while the highest was between neck width and body length. Molina et al. (1999) reported that the genetic correlations between body measurements within the Andalusian horse were all positive and ranged between 0.11 and 0.94 . These high correlations may be due to the same genes acting on these measurements but more likely are due to the low coefficient of variation for these measures (table 1). All phenotypic correlations among body measurements were positive with less magnitude than the genetic correlation.

Genetic and phenotypic correlations between body conformation indices are shown in table 4 . Some correlations coefficients were positive while some others were negative. The highest positive correlation (0.92) was between chest girt index and compactness index while the lowest positive correlation (0.07) was between body length index and compactness index. The lowest negative correlation (-0.43) was between chest girth index and boniness index. Molina et al., reported that the genetic correlations among body conformation scores within the Andalusian horse were all positive and ranged between 0.12 and 0.91 . Some phenotypic correlations between indices were positive while some others were negative but with less magnitude than the genetic correlations.

\section{CONCLUSION}

In Arabian horses, heritability estimates found in this investigation for body measurements were moderate to high, varying from 0.22 to 0.55 for most measurements except chest depth and wither height, meaning that these measurements may respond to a mass selection of varying degrees. For body conformation indices, estimates were low to medium. Most of the genetic correlations among body measurements were positively high. For body conformation indices, some genetic correlations estimates were positive while others were 
negative. Selection for certain body measures or conformation depends on the objectives of selection.

\section{REFERENCES}

Alagic, D., J. Seles, I. Seles, M. Mestrovic, 2002. Body measures and indices of the Holstein horses reared in Krizevci. Acta Agraria Kaposvariensis. 6(2):125-130.

Costa, M.D., J. A. G. Bergman, C. S. Pereira, C. G. Fonseca and A. S. C. Rezende, 1997. Estimation of genetic parameters of conformation traits in the Brasileira pony breed. Arq. Bras. Med. Vet. Zoot., 49:251-259.

Evans, J. W. 2000. A Guide To Selection, Care And Enjoyment. W. H. Freeman and company. New York, $3^{\text {rd }}$ ed. pp 62-80.

Fedorski, J and R. Pikuta 1987. Hritability of some body conformation traits in the thorughtbred horse. Anim. Sci. Papers and Reports. 3:53-59.

Iriarte-Diaz, J., 2002. Differential scaling of locomotor performance in small and large terrestrial mammals. J. Exp.Biology 205: 2897-2908.

Koenen, E. P. C., E. W. Brascamp and A. E. Van-Veldhuizen, 1995. Genetic parameters of linear scored conformation traits and their relation to dressage and show-jumping performance in the Dutch Warmblood riding horse population. Livestock Prod. Sci. 43:85-94.

Lawrence, L.A., 2001. Horse conformation analysis. Washington State University. Cooperative Extension .EB1613.pp1-7.

Loch, W., M. Bradley and W. H. Slemp, 2000. Fundamentals of conformation and horse Judging. Available online at http://www.horses-arizona.com/pages/ articles/conformation.html.

Meadows, D.G., 2003. Evaluating conformation of horses. Agricultural Extension Service .The University of Tennessee. TNH 6001. pp 6001.1-6001.7.

Miserani, M.G., C. McManus, S. A. Santos, J. A. Silva, A. S. Mariante, U. G. P. Abreu, M. C. Mazza and J. R. B. Sereno, 2002. Variance analysis for biometric measures of the Pantaneiro horses in Barazil. Arch. Zootec. 51: 113-120.

Meyer, K., 1998. DF-REML program, version 3-â. http://www.agbu.une.edu.au/ kmeyer/dfreml.html.

Molina, A., M. Valera, R. Dos Santos and A. Rodero, 1999. Genetic parameters of morphfunctional traits in Andalusian horse. Livestock Prod. Sci. 60:295-303.

Parker, R., 2002. Equine Science. Thomson Delmar Learning $2^{\text {nd }}$ ed. pp 188-206.

Saastamoinen, M. T., M. Suontama and M. Ojala. 1991. Heritability of conformation traits and their relationships to racing performance in the Finnhorse trotter. Acta Agric. Scand. 41: 137-145.

Samore, B., G. Pagnacco and F. Miglior, 1997. Genetic parameters and breeding values for linear type traits in the Haflinger horse. Livestock Prod. Sci. 52:105111.

WAHO, 2004. World Arabian horse organization. Available online at http://www.waho.org/Reports/Egypt.html.

Pietrzak, S and J. Wojciechowski, 1992. Comparative biometric characteristics of Polish primitive horse (PPH) from the main breeding centres. Animal Science Papers and Reports, Polish Academy of Science, Institute of Genetics and Animal Breeding Jastrzebiec. 8: 71-84. 


\section{تقير المعالم الوراثية والمظهرية لمقاييس الجسم وتكوينه في الخيول العربية}

قصم الإتتاج الحيوانسي، كلية الزراعة، جامعة عين شعس، ص ب 68، حدائق شبرا،، 11241، القاهرة،

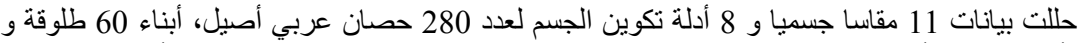

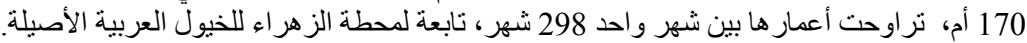

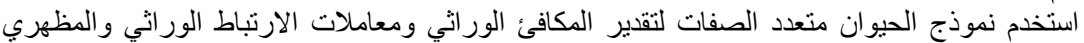

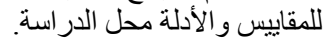

كانت تقدير ات المكافئ الور اثي

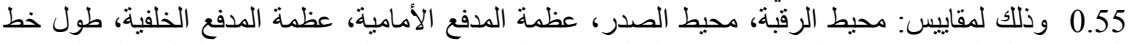

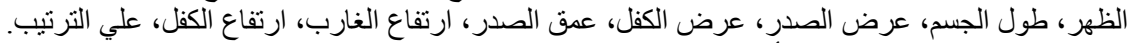

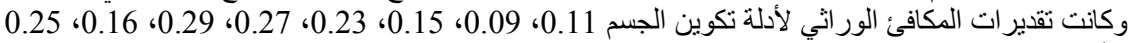

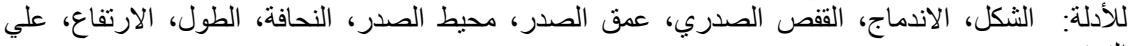

كانت تقدير ات معاملات الارتباط الور اثي جميعها موجبة وتراوحت بين 0.12 إلي 0.96 باستثناء معامل

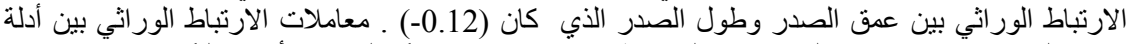

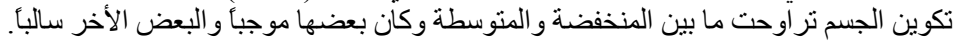

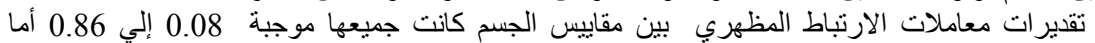

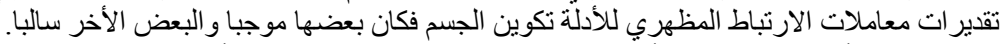

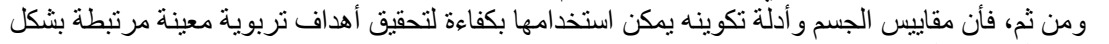

ومقاييس الحصان العربي. 